\title{
JARMAN 8: AN INDEX OF SOCIAL DISADVANTAGE
}

$\mathbf{R}$ elationships between social condition and health status continue to provide a focus for discussion of health care delivery. In particular, attention has focused on the use of indicators of socio-economic status which may appropriately measure social conditions and identify groups or areas of social disadvantage which may be associated with poor health. The Jarman 8 comprises one of several indices developed for this purpose, and has been the focus of a validation study conducted in Northern Sydney Area Health Service through the NSW Better Health Program.

The Jarman 8 is a census-based composite measure designed to identify underprivileged areas for purposes of health care resource allocation. The index was developed in England ${ }^{1,2}$. It comprises eight census elements considered most relevant to health care delivery on the basis of a national survey of general practitioners' perceptions of those characteristics most affecting their workloads. The index is used in England and Wales as the basis for special government payments to general practitioners working in socially deprived areas.

The index is calculated using eight variables from census data, which are then weighted (the figures shown in parentheses below) according to the average degree of importance given to them by the survey of general practitioners. The Jarman 8 index variables were recently adopted and validated in an Australian situation. The purpose of this study was to assess the index's links with health status ${ }^{3,4}$.

The variables in the Australian version of the index are:

- percentage of the population aged over 60 years and living alone (6.62);

- percentage of the population under 5 years old (4.62);

- percentage of the population living in single parent families (3.01);

- percentage of the population employed as labourers and related workers (3.01);

- percentage of the economically active population unemployed (3.74);

- percentage of the population living in overcrowded conditions (2.88);

- percentage of the population that changed address in the previous year (2.68); and

- percentage of the population born overseas from non-English speaking countries (2.50).

The Jarman 8 index was validated against a range of morbidity and premature mortality indices for a pilot area in NSW, the Northern Sydney Area Health Region. The calculations resulted in an association of between 54 and 60 per cent between census indicators and measures of health status. However, in recognition of the comparative social homogeneity of the region studied, there is a need for further validation of the index in wider and more socially heterogeneous settings.

The Jarman 8 study has been useful in raising discussion on the selection and use of socio-economic indicators which may be indicative of health status. Future work will assess the validity of the Jarman 8 index against other indices of socio-economic status.

The pilot study reported here suggests that the Jarman 8 index is a useful tool for strategic planning purposes through its ability to identify areas of disadvantage within broader regions.

The use of Jarman 8 as a composite measure of social disadvantage may also help dispel myths about the homogeneity of socio-economic and health status within broader NSW regions. This is especially true of more affluent health-advantaged regions, such as northern

\begin{tabular}{|c|c|}
\hline \multicolumn{2}{|l|}{ TABLE 1} \\
\hline $\begin{array}{l}\text { Most } \\
\text { advantaged: }\end{array}$ & $\begin{array}{l}\text { Bayview, Beecroft, Belrose, Carlingford, } \\
\text { Forestville, Gordon, Killara, Lindfield, Pymble, } \\
\text { St Ives. }\end{array}$ \\
\hline $\begin{array}{l}\text { More } \\
\text { advantaged: }\end{array}$ & $\begin{array}{l}\text { Castle Hill, Dural, Epping, Frenchs Forest, Hunters } \\
\text { Hill, Northbridge, Pennant Hills, Roseville, } \\
\text { Seaforth, Turramurra, Wahroonga. }\end{array}$ \\
\hline $\begin{array}{l}\text { Slightly } \\
\text { above average: }\end{array}$ & $\begin{array}{l}\text { Avalon Beach, Balgowlah, Brookvale, Church } \\
\text { Point, Collaroy Plateau, Eastwood, Mt Colah, } \\
\text { Palm Beach, Terrey Hills. }\end{array}$ \\
\hline $\begin{array}{l}\text { Slightly } \\
\text { below average: }\end{array}$ & $\begin{array}{l}\text { Asquith, Berowra, Berowra Heights, Collaroy } \\
\text { Beach, Cowan, Lane Cove, Mt Kuring-Gai, } \\
\text { Narrabeen, Newport Beach, North Ryde, } \\
\text { Spit Junction. }\end{array}$ \\
\hline $\begin{array}{l}\text { Less } \\
\text { advantaged: }\end{array}$ & $\begin{array}{l}\text { Cammeray, Chatswood, Cremorne Junction, } \\
\text { Crows Nest, Gladesville, Harbord, Mona Vale, } \\
\text { North Sydney, Willoughby. }\end{array}$ \\
\hline $\begin{array}{l}\text { Least } \\
\text { advantaged: }\end{array}$ & $\begin{array}{l}\text { Artarmon, Dee Why, Fairlight, Hornsby, Manly, } \\
\text { Milsons Point, Neutral Bay Junction, Ryde, } \\
\text { West Ryde. }\end{array}$ \\
\hline
\end{tabular}

\section{TABLE 2}

\section{NORTHERN SUBURBS RANKED}

FOR HEALTH STATUS

Highest status: Asquith, Beecroft, Belrose, Cowan, Dural, Forestville, Killara, Lindfield, Mt Kuring-Gai, Warriewood.

High status: Carlingford, Castle Hill, Cremorne Junction, Frenchs Forest, Gordon, Pymble, Roseville,

$\begin{array}{ll}\text { Slightly } & \text { Seaforth, Terrey Hills, Turramurra, Wahroonga. }\end{array}$

above average: Epping, Mt Colah, Northbridge, Palm Beach,

$\begin{array}{ll} & \text { Spit Junction, Willoughby. } \\ \text { Slightly } & \text { Avalon Beach, Gladesville, Hunters Hill, Hornsby, }\end{array}$

below average: Lane Cove, Mona Vale, Narrabeen, Pennant Hills, St lves, West Ryde.

Lower status: Artarmon, Balgowlah, Cammeray, Chatswood, Collaroy Beach, Collaroy Plateau, Dee Why, Milsons Point, North Ryde, North Sydney, Ryde.

Lowest status: Berowra, Church Point, Crows Nest, Fairlight, Harbord, Manly, Neutral Bay Junction. Newport Beach.

Sydney, where pockets of disadvantage are often overlooked. Being able to identify these pockets will ensure that the relative health advantage of the region as a whole is maintained by locating and focusing on those most in need of health-related programs.

The Jarman 8 can contribute to policy decision making and can also be used (with morbidity and mortality data) as a monitoring device to assess changes in health status within regions.

The project involving the piloting of the Jarman 8 index is available in two volumes from Pete Whitecross, Health Promotion Unit, Northern Sydney Area Health Service, phone (02) 438-7332.

Jim Forrest

Kevin McCracken

School of Earth Sciences, Macquarie University

Pete Whitecross,

Manager, Health Promotion Unit,

Northern Sydney Area Health Service

1. Jarman B. Identification of underprivileged areas, Brit Med J 1983 ; May:1705-1709.

2. Jarman B. Underprivileged areas: Validation and distribution of scores. Brit Med J 1984; 289, December:1587-1592.

cores. Brit Med J 1984; 289, December:1587-1592.

3. McCracken K, Forrest J. A manual for constructing the Jarman 8 index. Northern Sydney Area Health Service, 1991

4. Forrest J, McCracken K. The Jarman Score. A health needs study of Northern Sydney Area Health Service. Northern Sydney Area Health Service, 1991. 